\title{
Sun Protective Potential and Physical Stability of Herbal Sunscreen Developed from Afghan Medicinal Plants
}

\section{Afgan Tıbbi Bitkilerinden Geliştirilen Bitkisel Güneş Koruyucunun Güneş Koruyucu Potansiyeli ve Fiziksel Stabilitesi}

\author{
(D) Amina AHMADY1*, (D) Mohammad Humayoon AMINI², (D) Aqa Mohammad ZHAKFAR¹, (D) Gulalai BABAK¹, (D) Mohammad Nasim SEDIQI² \\ ${ }^{1}$ Kabul University Faculty of Pharmacy, Department of Pharmaceutics, Kabul, Afghanistan \\ 2Kabul University Faculty of Pharmacy, Department of Pharmacognosy, Kabul, Afghanistan
}

\begin{abstract}
Objectives: The aim of this study was to develop an herbal topical sunscreen formulation based on some fixed oils in combination with some medicinal plants.

Materials and Methods: The crude and purified extracts were screened for their phytochemical profile and their sun protection potentials. Based on our results, Elaeagnus angustifolia purified extract (EAPE), sesame oil, and sea buckthorn oil were selected for the development of the sunscreen formulation. The developed sunscreen formulations containing different concentration of EAPE were evaluated for their different physicochemical properties and stability.

Results: The results of the phytochemical analysis revealed the presence of phenolic compounds and flavonoids in all tested extracts. EAPE, sesame oil, and sea buckthorn oil showed the highest absorption in the ultraviolet region. The sun protection factor (SPF) value of the developed formulations containing different concentration of EAPE was in the range of $6.37 \pm 0.14$ to $21.05 \pm 0.85$. The sunscreen formulation containing $6 \%$ EAPE was stable for 8 weeks in an oven $\left(40^{\circ} \mathrm{C}\right)$ and refrigerator $\left(4^{\circ} \mathrm{C}\right)$.

Conclusion: The findings of this study revealed a higher sun protection capacity of EAPE than the other plant extracts. Sunscreen formulations containing 6\% EAPE showed promising SPF values. However, further in vivo studies are highly recommended to prove further the safety and efficacy of our developed sunscreen formulation.
\end{abstract}

Key words: Sunscreen, UV filter, emulgel, Elaeagnus angustifolia

öz

Amaç: Bu çalışmanın amacı, bazı tıbbi bitkiler ve sabit yağlar kullanılarak bir bitkisel güneş koruyucu geliştirmektir.

Gereç ve Yöntemler: Sabit yağların ham ve saflaştırılmış ekstreleri, fitokimyasal profilleri ve güneş koruma potansiyelleri açısından taranmıştır. Elde edilen sonuçlara dayanarak, güneş koruyucu formülasyonunun geliştirilmesi için Elaeagnus angustifolia saflaştırılmış ekstresi (EAPE), susam yağı ve yabani iğde yağı seçilmiştir. Farklı EAPE konsantrasyonları içeren geliştirilmiş güneş koruyucu formülasyonlar, farklı fizikokimyasal özellikleri ve stabiliteleri açısından değerlendirilmiştir.

Bulgular: Fitokimyasal analizler, test edilen tüm ekstrelerde fenolik bileşiklerin ve flavonoitlerin varlığını göstermiștir. EAPE, susam yağı ve yabani iğde yağı, ultraviyole bölgede en yüksek absorbsiyon göstermiştir. Farklı EAPE konsantrasyonları içeren geliștirilmiş formülasyonların güneș koruma

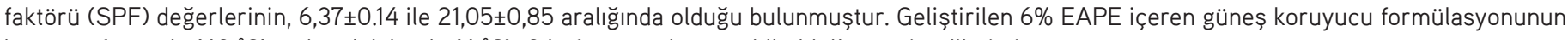
kurutma fırınında $\left(40^{\circ} \mathrm{C}\right)$ ve buzdolabında $\left(4^{\circ} \mathrm{C}\right) 8$ hafta süresince stabil olduğu tespit edilmiștir.

Sonuç: Bu çalışmanın bulguları, EAPE'nin diğer bitki ekstrelerden daha yüksek güneş koruma kapasitesine sahip olduğunu göstermiştir. \%6 EAPE içeren güneş koruyucu formülasyonun umut verici bir SPF değerine sahip olduğu bulunmuştur. Bununla birlikte sonuçlara göre geliştirdiğimiz güneş koruyucu formülasyonun güvenilirliğini ve etkinliğini kanıtlamak için ek in vivo çalışmaların yapılması oldukça önemlidir.

Anahtar kelimeler: Güneș koruyucu, UV filtresi, emulgel, Elaeagnus angustifolia

*Correspondence: E-mail: amina.ahmady@yahoo.com, Phone: +93747228758 ORCID-ID: orcid.org/0000-0001-6493-381X

Received: 19.11.2018, Accepted: 21.03.2019

-Turk J Pharm Sci, Published by Galenos Publishing House. 


\section{INTRODUCTION}

Exposure to solar ultraviolet (UV) radiation for a long time causes a variety of skin damage. Sunburn, skin pigmentation, premature aging, and photocarcinogenesis are some examples of skin damage due to UV radiation.,2 The main mechanism of skin damage by UV radiation is the formation of reactive oxygen species (ROS) that interact with proteins and lipids and subsequently alter them. ${ }^{3}$ UVC (200-280 nm), UVB (280-320 $\mathrm{nm})$, and UVA (320-400 $\mathrm{nm}$ ) are three subcategories of the UV region. UVB and to a lesser extent UVA are responsible for inducing skin damage. ${ }^{4,5}$

Although sunscreens have shown efficacy in prevention of sunburn, several studies indicate that they are not effective in prevention of skin carcinoma and premature aging. ${ }^{6,7}$ Currently it is very well understood that ROS are the main cause of skin damage such as skin cancer, actinic keratosis, and photoaging that happen due to chronic exposure to sunlight. Thus, the incorporation of antioxidants in addition to UV filters in formulations of sunscreens can improve the performance of sunscreens in the prevention of skin cancer and photoaging. ${ }^{5,8,9}$

Herbal extracts and oils have complex compositions, resulting in the exhibition of different effects, such as antioxidant, sun blocking, anti-inflammatory, and immunomodulatory.10,11 Moreover, the efficacy of herbal extracts in improving skin appearance and treatment of various skin diseases is very well understood. Plants due to their antioxidant potential are known as an attractive option to be used in sunscreen formulations for the prevention of skin damage due to solar radiation. $5,8,9,12$

Afghanistan is a mountainous country with a rich plant flora encompassing valuable nutritional and medicinal plants. The Afghan plant flora is estimated to be composed of around 3500 species (with 25-30\% endemics). ${ }^{13}$ The present work was designed in order to evaluate the sun protective potential of extracts and fixed oils extracted from some medicinal as well as nutritional plants growing in Afghanistan. In this research, sea buckthorn [Hippophae rhamnoides L. (H. rhamnoide)] ripe fruit oil, olive (Olea europaea) fruit oil, and sesame (Sesamum indicum) seed oil were tested by in vitro method for their sun protective potential. Similarly, Alhagi pseudalhagi ( $A$. pseudalhagi) herbs and Elaeagnus angustifolia (E. angustifolia) leaf extracts were screened for their phytochemical profile and sun protective potential. According to the results obtained from the preliminary studies on the sun protection potential of the aforementioned plants and fixed oils, a topical sunscreen formulation was developed.

\section{MATERIALS AND METHODS}

Chemicals

Different solvents such as methanol (MeOH) (Merck), ethanol (Merck), ethyl acetate, hexane (Sigma-Aldrich), petroleum ether (Sigma-Aldrich), and diethyl ether (Riedel-deHaen) were used in different steps of the extraction processes. Cetostearyl alcohol (CDH), butylated hydroxy toluene (BDH), sodium lauryl sulfate $(B D H)$, propylene glycol $(\mathrm{CDH})$, methyl paraben $(\mathrm{BDH})$, propyl paraben $(B D H)$, and xanthan gum $(B D H)$ were used for preparation of the emulgel formulation.

\section{Collection and identification of plant materials}

Mature fruits of $H$. rhamnoides were collected from Kapisa Province, located north of Kabul. Fresh leaves of E. angustifolia (family Elaeagnaceae) were collected from Paghman, a western district of Kabul Province. Aerial parts of $A$. pseudalhagi at blooming time were collected from the campus of Kabul University. The olive and sesame oils were procured from local markets in Jalalabad and Jowzjan, respectively.

All of the collected plants were botanically identified in the Pharmacognosy Dept., Kabul University (KU) by Prof. M.N. Sediqi. Prepared herbarium sheets of identified plants were kept as further reference in the herbarium of the Pharmacy Faculty, KU. The plant parts, after being shade dried, were ground into coarse powder and passed through mesh no: 1400 , and then were used in further experiments.

\section{Preparation of crude extracts of the plants}

Twenty grams of powdered A. pseudalhagi herb and powdered $E$. angustifolia leaves were extracted in a Soxhlet extractor at $70{ }^{\circ} \mathrm{C}$, and $70 \% \mathrm{MeOH}$ was used as solvent. The obtained $\mathrm{MeOH}$ extracts were filtered through filter paper (Whatman Number 1), and then were subjected to concentration at $40{ }^{\circ} \mathrm{C}$ under reduced pressure to get the crude semisolid extracts. For complete drying of the semisolid extracts, a drying oven (Yamato DX601) adjusted to $60{ }^{\circ} \mathrm{C}$ was used. Similarly, $20 \mathrm{~g}$ of dried powdered fruits of $\mathrm{H}$. rhamnoides was extracted by n-hexane at $70{ }^{\circ} \mathrm{C}$ using a Soxhlet extractor. The obtained extract was concentrated at $30{ }^{\circ} \mathrm{C}$ under reduced pressure in a Rotavapor to get $H$. rhamnoides fixed oil (HRO). The obtained orange colored HRO was further dried in an oven $\left(60{ }^{\circ} \mathrm{C}\right)$ to ensure complete removal of $n$-hexane (used as solvent) and constant weight of the HRO.

\section{Purification of the methanolic extracts}

The crude methanolic extracts of $A$. pseudalhagi purified extract (APCE) and E. angustifolia crud extract (EACE) were separately subjected to further purification by slightly modifying a method previously described by Jarzycka et al. ${ }^{14}$ Methanolic solutions of EACE and APCE were separately prepared in aqueous $\mathrm{MeOH}$ (70\%), which were then extracted by their equal volume of petroleum ether (4 times). The methanolic fractions of both extracts were dried and then their aqueous solutions in hot distilled water were prepared. Ascorbic acid was added to the aqueous extracts $(0.5 \mathrm{mg} / \mathrm{g})$ and the obtained mixtures were kept for $24 \mathrm{~h}$ in the refrigerator. Then the mixtures were washed with diethyl ether (5 times). Next, ethyl acetate (5 times) was used in extraction of the aqueous phases. The obtained ethyl acetate fractions of each plant's extracts were concentrated and dried to obtain purified extract of E. angustifolia (EAPE) and purified extract of $A$. pseudalhagi (APPE).

Dried extracts were separately dissolved in hot distilled water, followed by the addition of ascorbic acid $(0.5 \mathrm{mg} / \mathrm{g})$. The mixtures were kept in the refrigerator for $24 \mathrm{~h}$ and then were extracted with diethyl ether ( 5 times). Next, the aqueous fractions were extracted with ethyl acetate ( 5 times). The ethyl acetate fractions of each plant's extracts were dried and labeled as APPE and EAPE, which were used in further studies. 
Qualitative phytochemical screening of the extracts

Stock solutions of EACE, EAPE, APCE, and APPE were separately prepared in $\mathrm{MeOH}(2 \mathrm{mg} / \mathrm{mL}$ ) and were subjected to qualitative phytochemical tests as per prescribed methods ${ }^{15-18}$ for detection of the phytochemical classes present in the test extracts. The results of the qualitative phytochemical screening are presented in Table 1.

\section{Detection of alkaloids}

The following qualitative tests were performed for assessing the presence of alkaloids in the test extracts:

Dragendorff's test: Two milliliters of sample solution placed in a test tube was treated with 3 drops of Dragendorff's reagent. Formation of an orange red/brown precipitate indicates the presence of alkaloids. ${ }^{15}$

Hagers' test: Three drops of picric acid saturated solution were dropped on $2 \mathrm{~mL}$ of sample solution in a test tube. Appearance of yellow-whitish precipitate is proof of detection of alkaloids. ${ }^{15}$

Mayer's test: Three drops of potassium mercuric iodide solution were added to a test tube containing $2 \mathrm{~mL}$ of the sample solution. Appearance of a creamy or yellow precipitate shows the existence of alkaloids in test solution. ${ }^{15}$

Wagner's test: Three drops of solution of iodine were dropped on $2 \mathrm{~mL}$ of test solution in a clean test tube, and was observed for the formation of a brown or reddish-brown precipitate. ${ }^{15}$

\section{Detection of phenols}

$\mathrm{FeCl}_{3}$ test: Three drops of solution of $1 \% \mathrm{FeCl}_{3}$ were dropped onto $2 \mathrm{~mL}$ of sample solution in a clean test tube. Appearance of an intense greenish-black color shows the existence of phenolic compounds in the test sample. ${ }^{16}$

Lead acetated test: One milliliter of $10 \%$ solution of lead acetate was added to a test tube containing $2 \mathrm{~mL}$ of extract solution and was observed for the appearance of a bulky white precipitate. ${ }^{17}$

\section{Detection of flavonoids}

Alkali reagent test: About 3 drops of aqueous solution of $\mathrm{NaOH}$ (1 $\mathrm{N}$ ) were added dropwise to $2 \mathrm{~mL}$ of extract solution, and it was observed for the appearance of a yellow-orange color gradually increasing by addition of alkali drops. Adding some

Table 1. Results of phytochemical screening of plant extracts

\begin{tabular}{|c|c|c|c|c|c|}
\hline No. & Phytochemicals & EACE & EAPE & APCE & APPE \\
\hline 1 & Alkaloid & - & - & - & - \\
\hline \multirow[t]{3}{*}{2} & Phenols & & & & \\
\hline & $\mathrm{FeCl}_{3}$ test & + & + & + & + \\
\hline & Lead acetate test & + & + & + & + \\
\hline \multirow[t]{4}{*}{3} & Flavonoids & & & & \\
\hline & Alkali R. test & + & + & + & + \\
\hline & Ammonia test & + & + & + & + \\
\hline & Shinoda test & + & + & + & + \\
\hline \multirow[t]{2}{*}{4} & Tannin & & & & \\
\hline & Gelatin test & + & - & + & - \\
\hline
\end{tabular}

EACE: Elaeagnus angustifolia crud extract, EAPE: Elaeagnus angustifolia purified extract, APCE: Alhagi pseudalhagi crud extract, APPE: Alhagi pseudalhagi purified extract drops of diluted hydrochloric acid will diminish the intensity of the color produced. ${ }^{15,18}$

Ammonia test: A strip of filter paper impregnated with the test solution while dried was subjected to ammonia vapor. If an orange-red or yellow color appears on this strip, it shows the presence of flavonoids in the test extract. ${ }^{15}$

Shinoda test: Three drops of concentrated hydrochloric acid were added to $3 \mathrm{~mL}$ of test solution containing a small quantity of magnesium turnings, and it was left for completion of the reaction. If a pinkish color appears, it shows the existence of flavonoids in the test solution. ${ }^{15}$

\section{Detection of tannins}

Gelatin assay: About $2 \mathrm{~mL}$ of an aqueous solution containing 1\% gelatin and $10 \% \mathrm{NaCl}$ was mixed with $2 \mathrm{~mL}$ of sample solution in a clean test tube. If a whitish precipitate or a milky color forms, it shows that tannins are present in the test solution. ${ }^{19}$

\section{Measuring the UV spectrum of the extracts and fixed oils}

Methanolic solutions $(100 \mu \mathrm{g} / \mathrm{mL})$ of the extracts were separately prepared and were screened for their absorbance spectra in the range of 290 to $400 \mathrm{~nm}$, using a UV spectrophotometer (Shimadzu UV mini 1240). ${ }^{20}$ Similarly, hexane solutions of the fixed oils (1:100) were separately prepared and their absorbances in the range of 290 to $400 \mathrm{~nm}$ were recorded. ${ }^{21}$ The UV spectrum of extracts and fixed oils are shown in Figure 1 and Figure 2 respectively.

\section{Preparation of sunscreen emulgel}

The sunscreen formulation was developed from sesame oil, HR oil, and EAPE, which had shown the highest sun blocking properties in preliminary studies. The components of the emulgel base are presented in Table 2. The sunscreen was prepared by adding different concentrations of the EAPE (where $\mathrm{x}=2 \%, 4 \%, 6 \%$, and $8 \%$ ) to the formulation. The procedure for the preparation of emulgel involved the preparation of a gel phase by dissolving xanthan gum in a portion of purified hot water $\left(80^{\circ} \mathrm{C}\right)$ containing the appropriate amount of polyphenol fraction. Then it was left for $1 \mathrm{~h}$ to form a homogeneous gel. The oil and aqueous phases were heated separately to about 60 ${ }^{\circ} \mathrm{C}$ and then the aqueous phase was added to the oil phase with

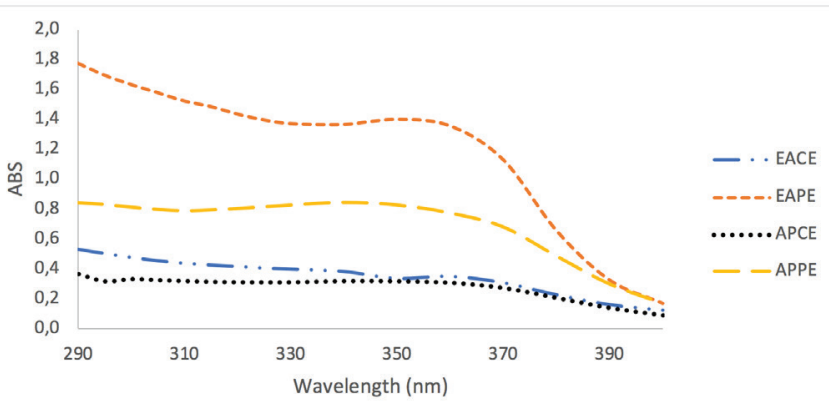

Figure 1. UV spectrum of methanolic solution of plant extracts at final concentration of $100 \mu \mathrm{g} / \mathrm{mL}$

UV: Ultraviolet, EACE: Elaeagnus angustifolia crud extract, EAPE: Elaeagnus angustifolia purified extract, APCE: Alhagi pseudalhagi crud extract, APPE: Alhagi pseudalhagi purified extract, ABS: Absorbance of sunscreen product 
continuous stirring. Afterward, the gel phase was added to the mixture and the formulation was mixed vigorously to cool the emulgel to room temperature.

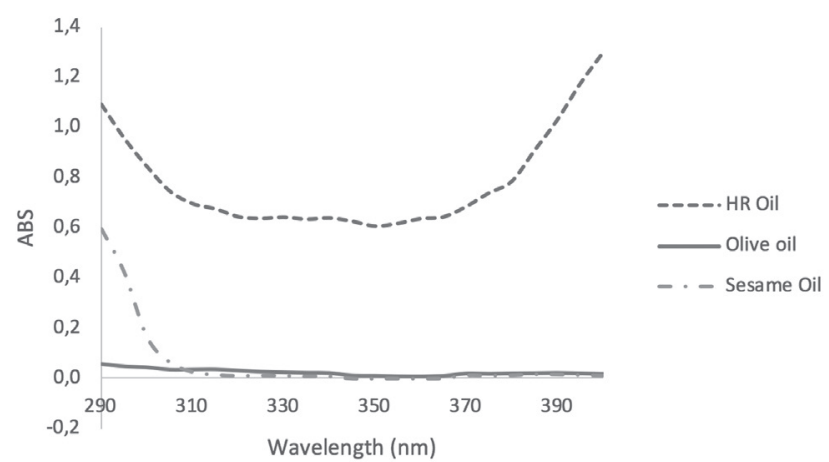

Figure 2. UV spectrum of Hippophae rhamnoides oil, olive oil, and sesame oil diluted 1:100 in hexane

UV: Ultraviolet, HR: Hippophae rhamnoides

\section{Table 2. Ingredients included in emulgel formulation}

\begin{tabular}{ll} 
Ingredients & Weight \% \\
\hline Phase A (oil phase) & \\
\hline Sesame oil & 14.5 \\
\hline Hippophae rhamnoides oil & 0.5 \\
\hline Cetostearyl alcohol & 5 \\
\hline Butylated hydroxy toluene & 0.05 \\
\hline Phase B (aqueous phase) & \\
\hline Sodium lauryl sulfate & 0.55 \\
\hline Propylene glycol & 5 \\
\hline Methyl paraben & 0.2 \\
\hline Propyl paraben & 0.1 \\
\hline Purified water & qsp \\
\hline Phase C (gel phase) & \\
\hline Xanthan gum & 0.5 \\
\hline EAPE & x \\
\hline Purified water & qsp \\
\hline
\end{tabular}

EAPE: Elaeagnus angustifolia purified extract

Table 3. Physical characteristics and SPF of emulgel formulation containing different concentrations of EAPE

\begin{tabular}{|c|c|c|c|c|c|}
\hline & Blank & SUNF $2 \%$ & SUNF $4 \%$ & SUNF $6 \%$ & SUNF 8\% \\
\hline Color & Light yellow & Yellow & Yellowish brown & Brown & Brown \\
\hline Emulsion type & O/W & O/W & $\mathrm{O} / \mathrm{W}$ & $\mathrm{O} / \mathrm{W}$ & $\mathrm{O} / \mathrm{W}$ \\
\hline Spreadability on the skin & Suitable & Suitable & Suitable & Suitable & Suitable \\
\hline $\mathrm{pH}$ & $8.04 \pm 0.16$ & $7.75 \pm 0.12$ & $7.32 \pm 0.12$ & $6.86 \pm 0.09$ & $6.39 \pm 0.06$ \\
\hline Precipitation & - & - & - & - & - \\
\hline SPF & $0.27 \pm 0.08$ & $6.37 \pm 0.14$ & $11.59 \pm 0.11$ & $16.03 \pm 0.12$ & $21.05 \pm 0.85$ \\
\hline
\end{tabular}

EAPE: Elaeagnus angustifolia purified extract, SPF: Sun protective factor, SUNF: Sunscreen formulation
Physicochemical evaluation of the developed sunscreen formulations

Formulations containing different concentrations of EAPE were evaluated in terms of emulsion type, color, spreadability on the skin, precipitate, $\mathrm{pH}$, and sun protective factor (SPF).

\section{Determination of $\mathrm{pH}$}

To measure the $\mathrm{pH}$ of the sunscreen formulation, $1 \mathrm{~g}$ of the sample was weighed and diluted with distilled water up to 10 $\mathrm{mL}$. The diluted sample was homogenized and then the $\mathrm{pH}$ of the sample solution was measured using a HM-25G model pH meter. ${ }^{22}$ The $\mathrm{pH}$ values of formulations containing different concentrations of EAPE are shown in Table 3.

\section{Determination of precipitation}

The centrifugation test provides information very quickly regarding the physical stability of the emulsion based system. To perform this test, $1 \mathrm{~g}$ of sample was weighed and centrifuged for $30 \mathrm{~min}$ at $3000 \mathrm{rpm}$. Then the weight of supernatant (separated phase) was measured. ${ }^{22}$

In vitro determination of the sun protective factor of the developed sunscreen formulations

Usually the SPF is used to express the sun protective capacity of sunscreens. ${ }^{23}$ There are many various in vivo and in vitro methods for determination of the SPF of sunscreen formulations. In the current work, the in vitro spectrophotometric method that was developed by Mansur et al. ${ }^{24,25}$ was used to measure the SPF of the sunscreen formulations containing different concentrations of EAPE. Ethanolic solutions of sunscreen formulations at the final concentration of $2 \mu \mathrm{L} / \mathrm{mL}$ were prepared. The absorption of samples was recorded in the range of 290-320 nm, every 5 $\mathrm{nm}$ using a UV-visible spectrophotometer (Shimadzu UV mini 1240). The SPF of the sunscreen formulations was calculated using the Mansur equation. Measurements were performed in triplicate and the results were shown as mean \pm standard deviation (SD).

$\operatorname{SPF}=C F \sum_{290}^{320} E(\lambda) \mid(\lambda) \operatorname{ABS}(\lambda)$,

where CF: Correction factor $(=10)$, ABS $(\lambda)$ : Absorbance of sunscreen product, $E E(\lambda)$ : Erythemal effect spectrum, and I $(\lambda)$ : Solar intensity spectrum. The values of EExl are constant, predetermined, and presented in Table $4 .{ }^{26}$ 


\section{Physical stability evaluation of sunscreen formulation}

Pharmaceutical or cosmetic products should be stable during their shelf life. Since the formulation containing 6\% extract had higher SPF and at the same time did not produce any color on the skin, it was selected for conducting physical stability studies. The stability studies were conducted in two storage conditions (oven at $40 \pm 2{ }^{\circ} \mathrm{C}$ and refrigerator at $4 \pm 2{ }^{\circ} \mathrm{C}$ ) for 8 weeks. The formulation was packaged in glass containers. The $\mathrm{pH}, \mathrm{SPF}$, precipitation, and organoleptic properties of samples were checked $7,14,21,28$, and 56 days after preparation. Each test was performed in triplicate and the results were recorded as mean \pm SD, as shown in Tables 5 and 6 and Figures 3 and 4 .

\section{Statistical analysis}

All measurements were conducted in triplicate and the results are presented as mean \pm SD. MS Excel 2016 was used for the statistical analysis. To assess the difference between different

\section{Table 4. Value of EExI used in the calculation of $\mathrm{SPF}^{26}$}

\begin{tabular}{ll} 
EEx| & Wavelength $(\mathrm{nm})$ \\
\hline 0.015 & 290 \\
\hline 0.0817 & 295 \\
\hline 0.2874 & 300 \\
\hline 0.3278 & 305 \\
\hline 0.1864 & 310 \\
\hline 0.0839 & 315 \\
\hline 0.018 & 320 \\
\hline
\end{tabular}

EE: Erythemal effect spectrum, I: Solar intensity spectrum variables, one-way ANOVA and Student's t-test were used. All analysis was performed at the $5 \%$ significance level $(p<0.05)$.

\section{RESULTS AND DISCUSSION}

\section{Phytochemical screening of the plant extracts}

The phytochemical screening involved the detection of flavonoids, phenolic compounds, tannins, and alkaloids in the extracts. The results are shown in Table 3 . The result of the alkaloids test was negative. Based on our findings, all extracts contain flavonoids and phenolic compounds, while the purified

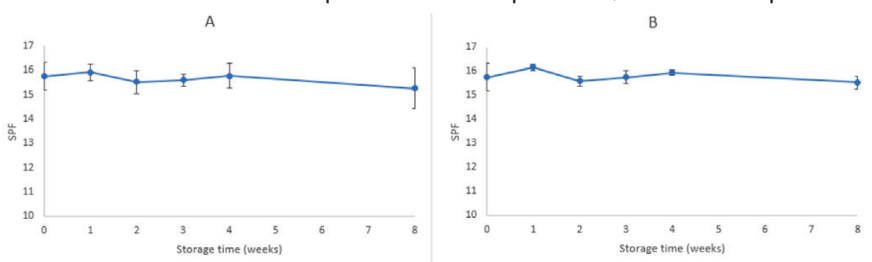

Figure 3. SPF changes in formulation containing 6\% EAPE during 8 weeks' storage at $40{ }^{\circ} \mathrm{C}(\mathrm{A})$ and $4{ }^{\circ} \mathrm{C}(\mathrm{B})$

SPF: Sun protective factor, EAPE: Elaeagnus angustifolia purified extract

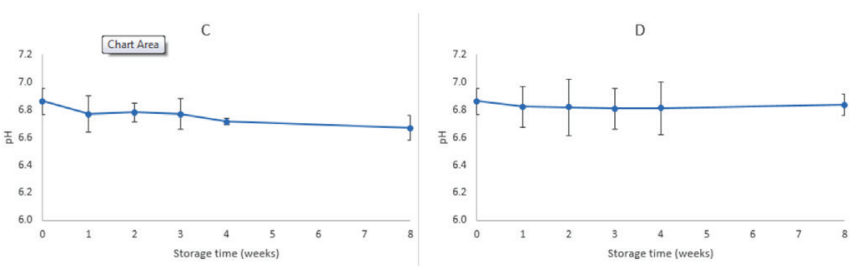

Figure 4. $\mathrm{pH}$ changes in formulation containing 6\% EAPE during 8 weeks storage at $40{ }^{\circ} \mathrm{C}(\mathrm{C})$ and $4{ }^{\circ} \mathrm{C}(\mathrm{D})$

EAPE: Elaeagnus angustifolia purified extract

Table 5. SPF and physical characteristics of emulgel formulation during 8 weeks' storage in the oven $\left(40{ }^{\circ} \mathrm{C}\right)$

Oven $\left(40^{\circ} \mathrm{C}\right)$

\begin{tabular}{llllll}
\hline & Week 1 & Week 2 & Week 3 & Week 4 & Week 8 \\
\hline SPF & $15.92 \pm 0.34$ & $15.53 \pm 0.48$ & $15.60 \pm 0.25$ & $15.77 \pm 0.51$ & $15.26 \pm 0.84$ \\
\hline $\mathrm{pH}$ & $6.77 \pm 0.13$ & $6.78 \pm 0.07$ & $6.77 \pm 0.11$ & $6.72 \pm 0.03$ & $6.67 \pm 0.09$ \\
\hline Precipitation & $0 \pm 0$ & $0 \pm 0$ & $0 \pm 0$ & $0 \pm 0$ & $0 \pm 0$ \\
\hline Phase separation & - & - & - & - & SLD \\
\hline Color change & SLD & SLD & SLD & SLD \\
\hline
\end{tabular}

SPF: Sun protective factor, SLD: Slightly darker than the sample at the time of preparation

Table 6. SPF and physical characteristics of emulgel formulation during 8 weeks' storage in the refrigerator $\left(4^{\circ} \mathrm{C}\right)$

Refrigerator $\left(4^{\circ} \mathrm{C}\right)$

\begin{tabular}{|c|c|c|c|c|c|}
\hline & Week 1 & Week 2 & Week 3 & Week 4 & Week 8 \\
\hline $\mathrm{pH}$ & $6.82 \pm 0.15$ & $6.82 \pm 0.2$ & $6.81 \pm 0.15$ & $6.81 \pm 0.19$ & $6.84 \pm 0.08$ \\
\hline Precipitation & $0 \pm 0$ & $0 \pm 0$ & $0 \pm 0$ & $0 \pm 0$ & $0 \pm 0$ \\
\hline Phase separation & - & - & - & - & - \\
\hline
\end{tabular}

SPF: Sun protective factor 
extracts (EAPE and APPE) were free of tannins. This may have been due to the low solubility of tannins in ethyl acetate.

\section{Sun protective capacity of extracts and fixed oils}

The UV spectra of the EACE, EAPE, APCE, and APPE are presented in Figure 1. The UV spectra of all plant extracts indicated that they have sun protective capacity in both the UVA and UVB regions. For nearly all extracts, the absorption was constant in the range of 290 to $370 \mathrm{~nm}$ and it decreased after $370 \mathrm{~nm}$. The order of UV absorption of the tested extracts was EAPE $>$ APPE $>$ EACE $>$ APCE. The purified extracts had higher absorption than the crude (methanolic) extracts. In the present research work the extracts were purified by the method previously developed by Wolski et al. ${ }^{26}$ for extraction of polyphenolic fractions.14,27 Polyphenols and flavonoids have been reported as sun protective agents in many published articles. $^{20,28-30}$ Thus the increased UV absorption by the methanolic solution of EAPE and APPE may be due to the higher concentrations of polyphenol and flavonoid compounds in the purified extracts. The UV spectra profile of the oil component including olive oil, sesame oil, and HRO is presented in Figure 2. Sesame oil and olive oil have negligible absorption compared with HRO. Olive oil has nearly the same absorption profile in both the UVA and UVB regions, but sesame oil showed more absorption in the range of 290 to $310 \mathrm{~nm}$. Therefore, sesame oil can provide better protection in the UVB region than olive oil can. Thus sesame oil was selected for use in the formulation. HRO showed very interesting absorption in both the UVA and UVB regions. In the present research work the oil of full dried fruit (seed and pulp) was extracted using hexane. This oil showed much higher absorption than the oil that was obtained from HR seeds by other researchers. ${ }^{31}$ The oil obtained from the full dried fruit (seed and pulp) had a strong orange color, which limited its use in high concentration in topical formulations.

\section{Physicochemical properties and SPF of the sunscreen formulations}

The physicochemical evaluation and SPF results of formulations containing different concentrations of EAPE are shown in Table 3. Incorporation of different percentages of the extract into the base cream caused some changes in the organoleptic properties of the emulgel formulations. The color of formulations ranged from light yellow for blank to brown for sunscreen formulation containing 8\% EAPE (SUNF 8\%). Following the administration on the skin, with the exception of SUNF $8 \%$, none of them produced any color on the skin. Therefore, the sunscreen formulation containing 6\% EAPE (SUNF 6\%) was selected for conducting stability studies, because it possessed higher SPF and did not color the skin. All formulations showed suitable viscosity and they easily were spread on the skin. The addition of extract into the base cream did not cause any visible change in the apparent viscosity or spreadability of the formulations. However, the formulations containing the extracts seemed to be less greasy. The $\mathrm{pH}$ of the formulations was in the range of 8.03 to 6.39 . In the sunscreen formulations as the extract concentration increased, the $\mathrm{pH}$ value of the formulations decreased. There was a negative linear correlation $\left(R^{2}=0.993\right)$ between the $\mathrm{pH}$ and concentration of extract in the sunscreen formulation. Our result is in agreement with other researchers' work. ${ }^{20,22}$ The $\mathrm{pH}$ value of the skin is in the range of 5 to $5.5 .^{32}$ In an ideal situation, especially in the case of topical formulations that are used frequently, the $\mathrm{pH}$ of a topical formulation should be slightly acidic in the range of 5 to 5.5 . However, in practice, a $\mathrm{pH}$ range of 5-7 is acceptable for topical formulations. ${ }^{33,34}$ Thus, SUNF $6 \%$ and SUNF $8 \%$ have a $\mathrm{pH}$ in the range $5-7$, which is acceptable for topical formulations. The SPF of formulations varied from $0.27 \pm 0.08$ for the base emulgel to $21.05 \pm 0.85$ for the formulation containing $8 \%$ EAPE, as shown in Table 3. The SPF of the base emulgel was negligible $(0.27 \pm 0.08)$, but the addition of extracts to the base cream caused a considerable increase in the SPF value of the emulgel formulations. There was a positive linear correlation $\left(R^{2}=0.999\right)$ between the SPF and concentration of the extract in the sunscreen formulations.

\section{Physical stability of the sunscreen formulations}

Tables 5 and 6 summarize the physical characteristics of the sunscreen formulations stored in the oven at $40{ }^{\circ} \mathrm{C}$ and in the refrigerator at $4{ }^{\circ} \mathrm{C}$, respectively. The following parameters were assessed for monitoring the physical stability during the 8 week storage period: SPF, pH, precipitation, occurrence of phase separation, and color change. These characteristics were observed at $40{ }^{\circ} \mathrm{C}$ (oven) and $4{ }^{\circ} \mathrm{C}$ (refrigerator) for 8 weeks. The centrifugation test provides fast and reliable information regarding the stability properties of formulations. ${ }^{16}$ There was no phase separation in the samples during storage in either condition. Even after the centrifugation, no phase separation was observed. There were minor changes in SPF values of formulations during storage at $40{ }^{\circ} \mathrm{C}$ (oven) and 4 ${ }^{\circ} \mathrm{C}$ (refrigerator). Figure 3 shows the changes in the SPF of the sunscreen formulation containing 6\% EAPE. We can say that there were no significant differences between the SPF of formulations over 8 weeks and the SPF values were stable. The $\mathrm{pH}$ of a topical formulation is an important characteristic that should be compatible with the formulation's other components and with the application site to avoid irritation. Thus measuring the $\mathrm{pH}$ of the formulation is necessary to ensure that the $\mathrm{pH}$ is stable during storage. $\mathrm{pH}$ changes in the sunscreen formulation containing 6\% EAPE are presented in Figure 4. The $\mathrm{pH}$ value changes were in the range of $6.86 \pm 0.13$ to $6.67 \pm 0.09$ and from $6.86 \pm 0.13$ to $6.84 \pm 0.08$ for samples stored in the oven and refrigerator, respectively. There were no significant differences in the $\mathrm{pH}$ of the formulation over 8 weeks. It was observed that the $\mathrm{pH}$ of the formulation was stable for 8 weeks in the two storage conditions. It was observed that during the storage time (oven and refrigerator) the organoleptic properties of the formulation were stable. The only change was related to a negligible color change in the sample that was kept in the oven. The color of the formulation seemed to be darker. This change was observed after 1 week.

\section{CONCLUSION}

In the present era, sunscreens are extensively used to prevent UV-induced skin damage including sunburn, early aging, 
and skin cancers. Recent research revealed that most of the synthetic sunscreens produce unwanted effects either in the short or long term of their application on the skin. Thus, there is an enormous need for effective and safe UV-filters around the world, particularly of natural origin. Fortunately, natural or herbal sunscreens are preferred because of being enriched with natural and safe compounds as compared with synthetic products. Based on the findings in the current work, the EAPE, which is rich in both flavonoids and polyphenols, exhibited high sun protective capacity. In the present work, the topical herbal sunscreen formulation containing sesame oil, HRO, and $6 \%$ EAPE showed an SPF value of 16.03 and was stable during 8 weeks' storage in the refrigerator at $4{ }^{\circ} \mathrm{C}$ and oven at 40 ${ }^{\circ} \mathrm{C}$. However, further in vivo studies are highly recommended to further prove the safety and efficacy of the developed sunscreen formulation.

\section{ACKNOWLEDGEMENT}

This research work was funded by Family Health International under Cooperative Agreement no: AID-306-A-13-00009-00 funded by USAID. The publication's content does not generally reflect the view, analysis, or policies of $\mathrm{FHI} 360$ nor does any mention of commercial products, organizations, or tradename indicate endorsement by $\mathrm{FHI} 360$ or USAID. The authors are very grateful to the Afghan Ministry of Higher Education for providing all facilities and support to conduct this research work.

Conflicts of interest: No conflict of interest was declared by the authors. The authors alone are responsible for the content and writing of the paper.

\section{REFERENCES}

1. Lakhdar H, Zouhair K, Khadir K, Essari A, Ricard A, Seite S, Rougier A. Evaluation of the effectiveness of a broad-spectrum sunscreen in the prevention of chloasma in pregnant women. J Eur Acad Dermatol Venereol. 2007;21:738-742.

2. Wolf R, Tüzün B, Tüzün Y. Sunscreens. Dermatol Ther. 2001;14:208-214.

3. Imam S, Azhar I, Mahmood ZA. In-vitro evaluation of sun protection factor of a cream formulation prepared from extracts of musa accuminata (L.), psidium gujava (L.) And pyrus communis (L.). Asian J Pharm Clin Res. 2015;8:234-237.

4. Chanchal D, Swarnlata S. Herbal Photoprotective Formulation and their Evaluation. Ope Nat Prod J. 2009;2:71-76.

5. Afaq F, Mukhtar H. Botanical Antioxidant in the Prevention of Photocarcinogenesis and Photoaging. Exp Dermatol. 2006;15:678-684.

6. Gasparro FP. Sunscreen, Skin Photobiology, and skin cancer: The Need for UVA Protection and Evaluation of Efficacy. Environ Health Perspect. 2000;108:71-78.

7. Vainio $H$, Miller $A B$, Bianchini $F$. An International Evaluation of the Cancer Preventive Potentioal of Sunscreens. Int J Cancer. 2000;88:838842.

8. Afaq F, Mukhtar H. Photochemoprevention by Botaanical Antioxidants. Skin Pharmacol Appl Skin Physiol. 2002;15:297-306.
9. Chermahini SH, Majid FAA, Sarmadi MR. Casmeceutical Value of herbal extracts as natural ingredient and novel technologies in anti aging. $\mathrm{J}$ Med Plants Res. 2011;5:3074-3077.

10. Psotova J, Svobodova A, Kolarova H, Walterova D. Photoprotective properties of Prunella vulgaris and rosmarinic acid on human keratinocytes. J Photochem Photobiol B. 2006;84:167-174.

11. Aquino R, Morelli S, Tomaino A, Pellegrino M, Saija A, Grumetto L, Puglia C, Ventura D, Bonina F. Antioxidant and photoprotective activity of a crude extract of Culcitium reflexum H.B.K. leaves and their major flavonoids. J Ethnopharmacol. 2002;79:183-191.

12. Korac RR, Khambholja KM. Potential of herbs in skin protection from ultraviolet radiation. Pharmacogn Rev. 2011;5:164-173.

13. Breckle SW, Rafiqpoor MD. Field Guide Afghanistan: Flora and Vegetation. Germary: Scientia Bonnensi; 2010:430

14. Jarzycka A, Lewinska A, Gancarz R, A wilk K. Assessment of extracts of Helichrysum arenarium, Crataegus monogyna, Sambucus nigra in photoprotective UVA and UVB; photostability in cosmetic emulsions. J Photochem Photobiol B. 2013;128:50-57.

15. Shah B, Seth AK. textbook of pharmacognosy and phytochemistry (1st ed). Haryana: Elsevier; 2010:189;234-236.

16. Harborne A. Phytochemical Methods: A guide to modern techniques of plant analysis ( $3^{\text {rd }}$ ed). Springer. 1998:31-110.

17. Banu KS, Cathrine L. General Techniques involved in Phytochemical Analysis. Int J Adv Res Chem Sci. 2015;2:25-32.

18. Bhandary SK, Kumari N.S, Bhat VS, Sharmila KP, Bekal MP. Preliminary phytochemical screening of various extracts of Punica granatum peel, whole fruit and seeds. NUJHS 2012;2:34-38.

19. Evans WC. Trease and Evans Pharmacognosy (16 th ed). London; SAUNDERS; 2009;136:616.

20. Tabrizi H, Mortazavi SA, Kamalinejad M. An in vitro evaluation of rosa damascena flower extracts as a natural antisolar agent. Int J Cosmet Sci. 2003;25:259-265.

21. Oomaha D, Ladet S, Godfrey DV, Liang J. Girard B. Characteristics of raspberry (Rubus idaeus L.) seed oil. Food Chemistry. 2000;69:187-193.

22. Kim SH, Jung EY, Kang DH, Chang UJ, Hong YH, Suh HJ. Physical stability, antioxidative properties, and photoprotective effects of a functionalized formulation containing black garlic extract. J Photochem Photobiol B. 2012;117:104-110.

23. Salvador A, Chisvert A. Analysis of Cosmetic Product, Amsterdam: Elsvire; 2007:94

24. Mansur JDS, Breder MNR, Mansur MCA, Azulay RD. Determinação do fator de proteção solar por espectrofotometria. An Bras Dermatol. 1986;61:121-124

25. Santos EP, Freitas ZM, Souza KR, Garcia S, Vergnanini A. In vitro and in vivo determinations of sun protection factors of sunscreen lotions with octylmethoxycinnamate. Int J Cosmet Sci. 1999;21:1-5.

26. Wolski T, Ludwiczuk A, Baj T, Glowniak K. Genus Panax taxonomy chemical composition pharmacological effects medicinal application and phytochemical analysis of aerial and underground parts of american ginseng (Panax quinquefolium L.). Method of extraction and determination of phenolic compounds. Postepy Fitoterapii. 2008;4: 206-223.

27. Dutra AE, Oliveria, AGC, Kedor-Hackmann ERM, Santoro Miritello IRM. Determination of sun protection factor (SPF) of sunscreen by ultraviolet spectrophotometry. Braz J Pharm Sci. 2004;40:381-385. 
28. Ebrahimzadeha MA, Enayatifard R, Khalilia M, Ghaffarloo M, Saeedi M, Charati JY. Correlation between Sun Protection Factor and Antioxidant Activity, Phenol and Flavonoid Contents of some Medicinal Plants. Iran J Pharm Res. 2014;13:1041-1047.

29. Baliga MS, Katiyar SK. Chemoprevention of photocarcinogenisis by selected dietary botanicals. Photochem Photobiol Sci. 2006;5:245-253.

30. Bonina F Lanza M, Montenegro L, Puglisi C, Tomaino A, Trombetta D, Castelli F, Saija A. Flavonoids as potential protective agents against photo-oxidative skin damage. Int J Pharm. 1996;145:87-94.
31. Beveridge T, Li TSC. Oomah BD, Smith A. Sea Buckthorn Products: Manufacture and Composition. J Agric Food Chem. 1999;47:3480-3488.

32. Betz G. Aeppli A, Menshutina N, Leuenberger H. In vivo comparison of various liposome formulations for cosmetic application. Int J Pharm. 2005;296:44-54.

33. Benson HAE, Watkinson AC. Transdermal and Topical Drug Delivery: Principles and Paractice. New Jersey: John Wiley \& Sons; 2012:268.

34. Wiechers JW, Solutions JW. Formulating at $\mathrm{pH} 4-5$ : How Lower $\mathrm{pH}$ Benefits the Skin and Formulations. Cosmetics Toileters. 2013. 